\title{
Graefe's Archives for Clinical and Experimental Ophthalmology: the past and the future
}

\author{
David Wong • Antonia M. Joussen
}

Received: 12 November 2011 / Accepted: 15 November 2011 / Published online: 30 December 2011

(C) The Author(s) 2011. This article is published with open access at Springerlink.com

This issue is the commencement of the 250th volume of Graefe's Archive for Clinical and Experimental Ophthalmology — a proud timeline for the journal.

To predict the future, one has to acknowledge the past. Last year the journal's impact factor increased to 2.1. To guarantee and continue with this success we, as Editor-in-Chiefs, need to know how this was achieved. Who contributed to the journal? Who downloaded our articles? Which articles were the most cited? Perhaps most relevant to our readers, why should they submit to our journal?

The last question is probably the easiest to answer. The journal is going from strength to strength. The numbers speak for themselves. Graefe's distribution has increased significantly, especially to institutions. The number of institutions subscribing to the journal has increased from 5,350 in 2008 to 8,005 in 2010. Of course, nowadays usage of the journal often takes the form of online download. In 2008, the number of full-article downloads was 140,750. By 2010, this number increased to 237,479 . The purpose of publication is to

\section{A. M. Joussen}

Department of Ophthalmology,

Charité, University Medicine Berlin,

Virchowklinikum (CVK),

Augustenburger Platz 1,

13353 Berlin, Germany

\section{A. M. Joussen}

Klinikum Steglitz (CBF),

Hindenburgdamm 30,

12200 Berlin, Germany

\section{Wong $(\triangle)$}

The Eye Institute, LKS Faculty of Medicine,

The University of Hong Kong,

Pokfulam, Hong Kong SAR, People's Republic of China

e-mail: shdwong@hku.hk disseminate information. These figures alone should persuade authors to consider submitting to our journal.

Access to the journal is predominantly online; it is therefore possible to know who uses the journal. In terms of downloads, the distribution is about one third from Europe and one third from Asia-Pacific, with less than one quarter from North America. The country with the most frequent full-article download is USA, accounting for 19\% of all downloads, followed by Germany and China at $9 \%$ and $8 \%$ respectively. And how do readers search for our articles? You may be surprised that the answer is that Google and Pubmed are now equally as popular as the academic search engine.

The number of articles being submitted has also significantly increased. In 2008, we received 841 articles. In 2010, this increased to 1,055. Geographically, most submissions are from Germany at 138 articles followed by China at 128, USA 99 and Japan 87. These four countries together contributed half of all articles published. Although Germany is clearly in the lead in the league table of contributors, there is no doubt that the journal is not only European but truly global, with authors from 51 countries submitting to Graefe's.

As open-access case-report journals have become more popular, the trend for many international journals is to accept fewer case reports. In 2010, we published 205 original articles, but only 17 case reports. We, however, always welcome letters to the editor, many of which have proven to be highly interesting. In the coming 12 months, we have solicited worldleading pathologists to prepare a series of review articles covering different aspects of ocular pathology. We hope that readers will find these updates useful, and that trainees will download and study them.

The list of the top ten most cited articles in Graefe's are given below (Table 1). Seven of the top ten dealt with topics related to the retina. Only four of the ten are review articles. 
Table 1 Top ten articles downloaded in 2010 (source: Coremetrics)

\begin{tabular}{|c|c|c|c|c|}
\hline Title & Volume & Issue & Year & $\begin{array}{l}\text { Article requests } \\
\text { Jan to Nov } 2010\end{array}$ \\
\hline A review of clinical trials of anti-VEGF agents for diabetic retinopathy & 248 & 7 & 2010 & 1,695 \\
\hline $\begin{array}{l}\text { Three-dimensional ultrasound biomicroscopy, environmental and } \\
\text { conventional scanning electron microscopy investigations of the } \\
\text { human zonula ciliaris for numerical modelling of accommodation }\end{array}$ & 244 & 7 & 2006 & 767 \\
\hline $\begin{array}{l}\text { Verteporfin PDT for non-standard indications - a review of current } \\
\text { literature }\end{array}$ & 248 & 5 & 2010 & 637 \\
\hline $\begin{array}{l}\text { Non-arteritic anterior ischemic optic neuropathy: role of systemic } \\
\text { corticosteroid therapy }\end{array}$ & 246 & 7 & 2008 & 591 \\
\hline $\begin{array}{l}\text { A tissue-engineered approach towards retinal repair: scaffolds for cell } \\
\text { transplantation to the subretinal space }\end{array}$ & 248 & 6 & 2010 & 549 \\
\hline $\begin{array}{l}\text { A systematic review on the effect of bevacizumab in exudative } \\
\text { age-related macular degeneration }\end{array}$ & 247 & 1 & 2009 & 519 \\
\hline $\begin{array}{l}\text { Treatment of neovascular age-related macular degeneration with a } \\
\text { variable ranibizumab dosing regimen and one-time reduced-fluence } \\
\text { photodynamic therapy: the TORPEDO trial at } 2 \text { years }\end{array}$ & 248 & 7 & 2010 & 475 \\
\hline $\begin{array}{l}\text { Intravitreal triamcinolone acetonide versus bevacizumab therapy for } \\
\text { macular edema associated with branch retinal vein occlusion }\end{array}$ & 248 & 7 & 2010 & 451 \\
\hline $\begin{array}{l}\text { Twelve-month safety of intravitreal injections of bevacizumab } \\
\text { (Avastin }(\text { ) : results of the Pan-American Collaborative Retina Study } \\
\text { Group (PACORES) }\end{array}$ & 246 & 1 & 2008 & 441 \\
\hline $\begin{array}{l}\text { Amyloid precursor protein processing and retinal pathology in mouse } \\
\text { models of Alzheimer's disease }\end{array}$ & 247 & 9 & 2009 & 423 \\
\hline
\end{tabular}

The majority of the most frequently cited articles are clinical, with only two of the ten predominantly laboratory-based research.

After 250 years, Graefe's Archive is now predominantly online; it still has a retinal focus; the journal is truly global, being contributed and accessed by all people across the world. As editors, we are transient custodians, fully aware of the journal's strong tradition and our own responsibility to ensure its continued success.

Open Access This article is distributed under the terms of the Creative Commons Attribution Noncommercial License which permits any noncommercial use, distribution, and reproduction in any medium, provided the original author(s) and source are credited. 